\title{
Short Communication: Agroforestry as sustainable agroecosystem in terrestrial semi-arid region, Indonesia: Evidence from soil organic carbon
}

\author{
MELINDA R.S. MOATA", AYDAM MEEL TAKALAPETA \\ Department Dryland Farming, Politeknik Pertanian Negeri Kupang. Jl. Prof. Dr. Herman Johanes, Lasiana, Kota Kupang 85361, East Nusa Tenggara, \\ Indonesia. Tel.: +62-380-881600, `email: melinda.moata@ staff.politanikoe.ac.id; rosita.moata @ gmail.com
}

Manuscript received: 1 January 2021. Revision accepted: 24 April 2021.

\begin{abstract}
Moata MRS, Takalapeta AM. 2021. Short Communication: Agroforestry as sustainable agroecosystem in terrestrial semi-arid region, Indonesia: Evidence from soil organic carbon. Intl J Trop Drylands 5: 1-4. Agroforestry system has been recognized as a better system for food security, especially during dry season in a tropical region. Therefore, the sustainability of this system becomes crucial for rural livelihood, especially in dryland areas. One indicator for sustainable agriculture system is the total amount and quality of the soil organic matter (SOM) which is expressed as soil organic carbon (C-org). Therefore, this study focused on soil quality of three land uses (forest, dryland agriculture with less input, and agroforestry) under Inceptisol, Entisol, and Alfisol from 36 locations at dryland terrestrial ecosystem in West Timor-Indonesia. The results showed that all soils are dominated by clay and silt loam textures (54\%) and neutral $\mathrm{pH}(83 \%)$ but still have very low SOM and C-org < 1\% (48\%). However, a mixed cropping system (agroforestry) provides a higher C-org compound (5\% C-org) than other land uses $(<1 \% \mathrm{C}$-org). Carbon has a strong correlation with nitrogen $(r=0.90, \mathrm{p}=$ $0.0004)$, weak correlation with potassium $(r=0.51, \mathrm{p}=0,13)$ and correlation with phosphorus-P $(r=0.30, \mathrm{p}=0.40)$. The SOM in these terrestrial ecosystems has a moderate correlation with Cation Exchange Capacity (CEC) $(r=0,64, \mathrm{p}=0.04)$. It is indicated that most of the soil nutrients and CEC were influenced by SOM (C-org) except P (likely from mineral soil). It is a promising finding that agroforestry is a sustainable system for agriculture where SOM could be key driver for land productivity in the terrestrial ecosystem.
\end{abstract}

Keywords: $\mathrm{C} / \mathrm{N}$ of soil, land uses, West Timor

\section{INTRODUCTION}

From the perspective of agro-ecology, dryland can be defined as un-irrigated land, up-land, or not permanently irrigated land (Anonymous 1997). East Nusa Tenggara (ENT), as one of 34 provinces in Indonesia, is located in the semi-arid region and is dominated by dryland $(94 \%)$ and only 6\% wetland (Nur 2018). This province comprises 11 agro-ecological zones based on climate, temperature, slope, physiography, land uses, type of commodity, and soil (BPTP NTT 2007). West Timor area, the Indonesian part of Timor Island and administratively under ENT Province, consists of four regencies (Kupang, Timor Tengah Selatan/TTS, Timor Tengah Utara/TTU, and Belu) and one municipality. The variation of climate, physiography, and soil in West Timor produces different land use systems which are the combination of agriculture, forestry and grazing lands (Aldrik 1984) developed in dryland agroecosystems. The mixed farming system is established in every village in ENT and is called a community garden or Mamar. Large numbers of local trees are grown in the Mamar which are adaptive to certain areas for a long time. This system has supported the sustainability of agriculture, forest, environment and sociocultural.

For agroecosystem development, land productivity is a critical factor besides stability, sustainability, and equitability. One indicator of land productivity is soil fertility related to soil organic matter (SOM) (Haynes 2005). In this regard, soil organic carbon (C) can be used as an indicator of soil quality that benefits soil management strategy, food production, and agricultural sustainability (Ramesh et al. 2015). There are several pools of SOM, such as stabile pool (humus), labile pool (particulate organic matter-POM), and inert organic matter pool (IOM) (Baldock and Skjemstad 1999; Six 2001; Clapp 2005; Haynes 2005). Carbon (C) storage in the soil varies among SOM pools which are impacted by land-use changes. Therefore, SOM structure is an essential factor in understanding the effect of land uses and soil quality. For example, grassland could increase $\mathrm{C}$ level at whole soil, humus, and POM but not for IOM. Carbon in coarse fraction $(\mathrm{POM})$ has a significant correlation with $\mathrm{P}$ than a fine fraction (humus), and only organic P pools have a close correlation with $\mathrm{C}$, especially soil microbe pools (Moata et al. 2016). When the land is used for intensive agricultural systems, the $\mathrm{C}$ level decreases, especially for the un-stabile fraction. Stoichiometry between the organic and inorganic forms of soil nutrients will affect Csequestration or nutrient release. Therefore, understanding the relationship between $\mathrm{C}$ and nutrients cycle is necessary.

Stoichiometry of $\mathrm{C}$ and soil nutrients varies depending on soil type, land uses, climate, and SOM fractions (Barrett 2007). A study on fine fraction of soil $(<0.4 \mathrm{~mm})$ from some agro-ecological zone in Australia found that high clay 
soil has C:N (10.6) and C:P (40) comparable to loamy soil (11.9 and 40). However, sandy soil has higher C:N and C:P with 13.3 and 60, respectively, and the highest one is sandy clay loam $(\mathrm{C}: \mathrm{N}=12.3$ and $\mathrm{C}: \mathrm{P}=97$ ) (Kirkby et al. 2011; Kirkby et al. 2013). Forest land has similar C:N with that of grassland but it has different $\mathrm{C}: \mathrm{P}$ and $\mathrm{N}: \mathrm{P}$ ratios (Clevel and Liptzin 2007). The stoichiometry of C:N:P also varied among agricultural systems (Moata et al. 2015). The variation was probably due to the source of $\mathrm{C}$ and $\mathrm{N}$ that are mainly from vegetation biomass, while $\mathrm{P}$ is mainly from mineralization of SOM and weathered rock. The C:N ratio of soil biomass from forest and mineral soils does not change much with time (Yang and Luo 2011). Stoichiometry of $\mathrm{C}: \mathrm{N}: \mathrm{P}$ varies among clime zones. Tropical and sub-tropical regions with high temperatures and rainfall could produce large biomass and increase $C$ input returned to the soils. Therefore the C:P and N:P were higher in a cooler areas, ice, warm, or four seasons places while C:N was not changed (Tian et al. 2010). This might have happened due to enzymatic activities where $\mathrm{P}_{\text {tot }}$ and $\mathrm{C}$ will increase along with the increase of temperature and precipitation (Sinsabaugh et al. 2008). Thus, soil factors, land uses, and climate become essential factors in determining the stoichiometry of soil nutrients besides other factors that influence $\mathrm{N}$ and $\mathrm{P}$ availability in the terrestrial ecosystem.

This study aimed to assess the stoichiometry of C:N:P in semi-arid region in ENT Province, Indonesia. In doing so, we focused on dryland areas in West Timor region by taking adequate samples representing various agroecological zones. We expected the results of this study can inform strategy for developing agricultural systems in the region based-on the stoichiometry of $\mathrm{C}: \mathrm{N}: \mathrm{P}$.
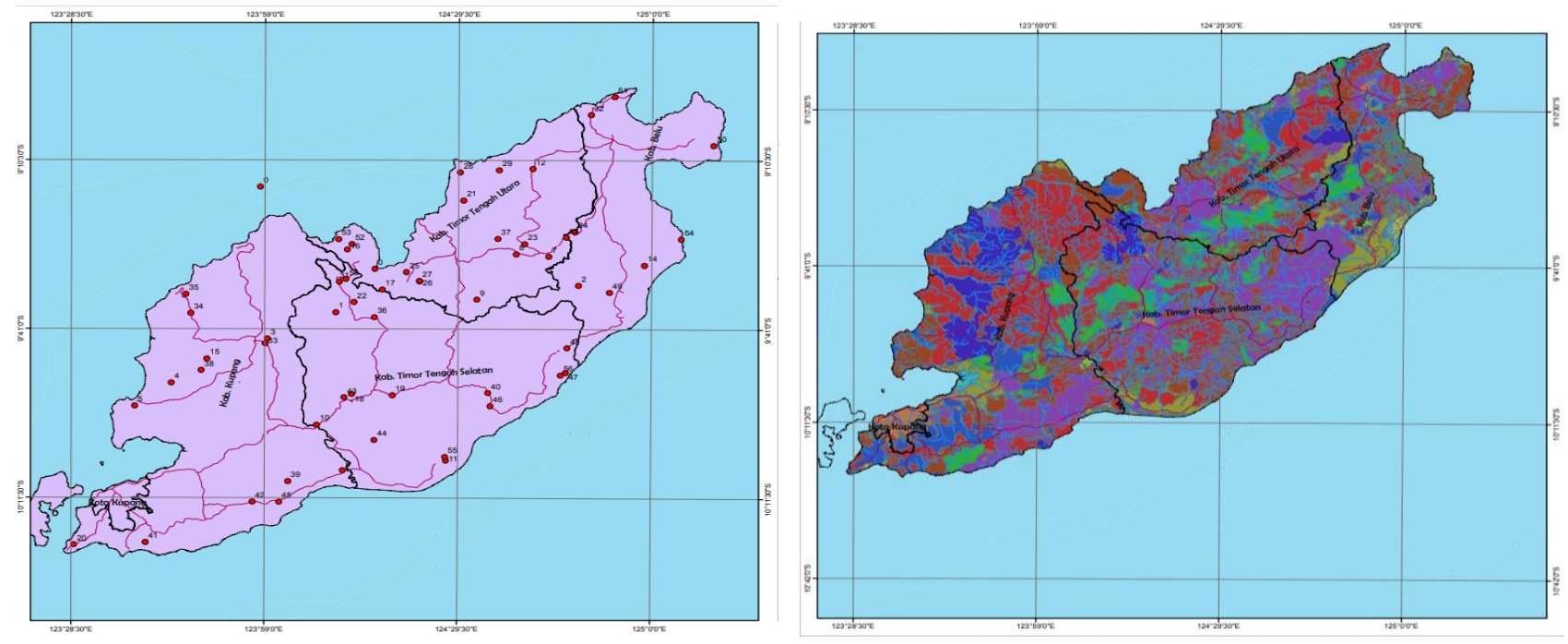

Figure 1. A. Sampling sites in West Timor region; B. Land uses map in West Timor region, Indonesia 

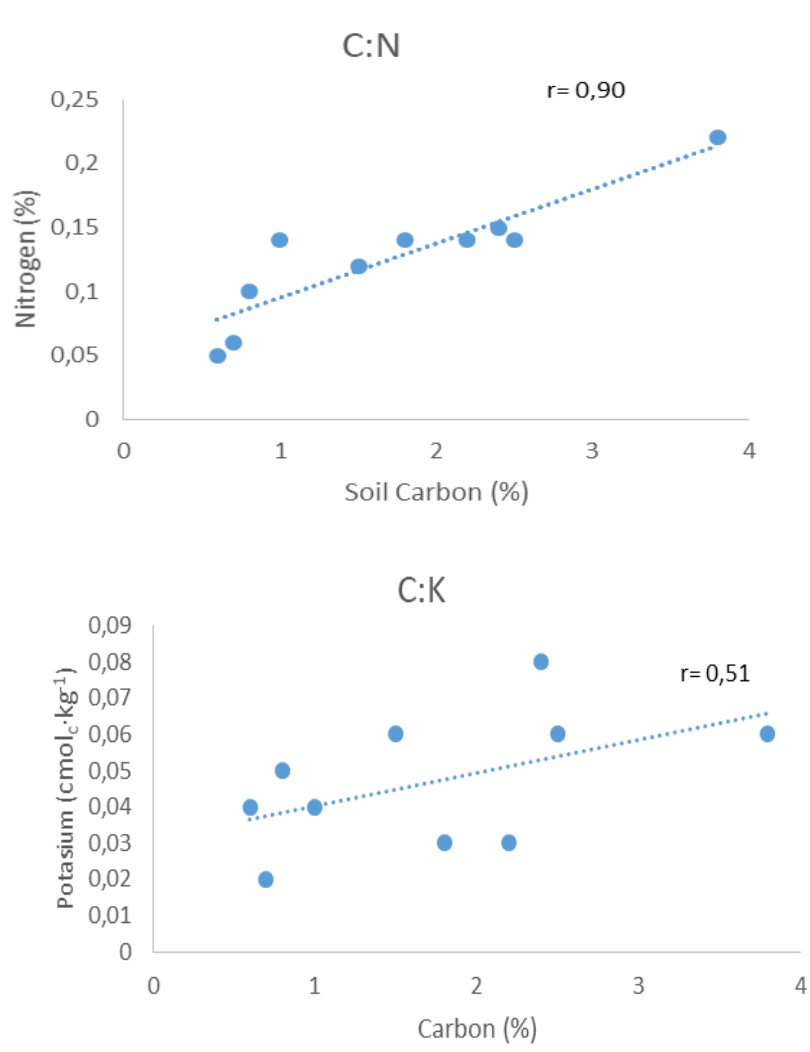
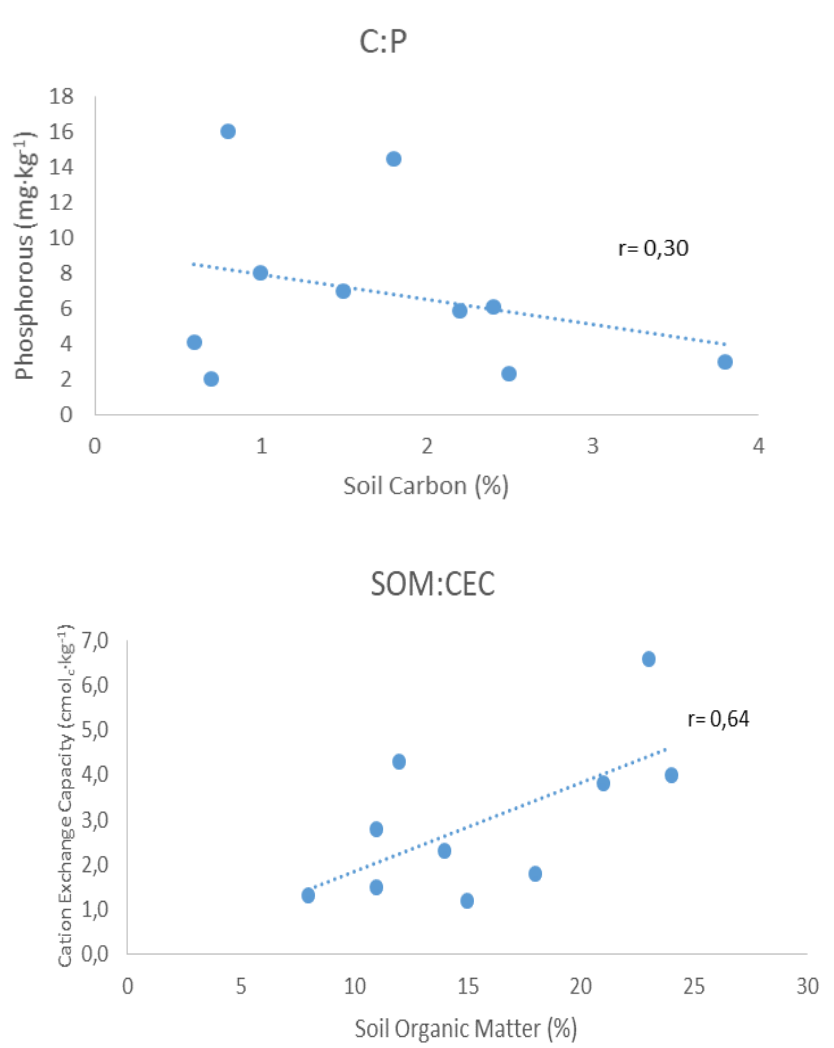

Figure 2. Regression of soil Carbon to N, C:P, K dan Soil organic matter to Cation Excgane capacity

The quality of soils is comparable among regencies in Timor Island of ENT. The previous study (Moata et al. 2018) revealed that the Kupang Regency area has mainly clay loam and clay soils (43\%) with average clay content $37 \%$. The soils have neutral soil pH 6.6-7.3 (85\%), C-org is low to very low $<1-2 \%(67 \%)$ though few soils have high C-org of $3-4 \%(11 \%)$ of total soils. Meanwhile, the TTS Regency area has silty loam soil $(65 \%)$ and sandy loam $(17 \%)$. These soils are slightly acidic with $\mathrm{pH}$ of $6.5(35 \%)$ and the rest are neutral (65\%). For Kupang soils, C-org was low to very low level (55\%), and medium level 2-3\% $(27 \%)$, and the rest $8 \%$ was high to very high C-org levels (3-5\%). On the other hand, Belu Regency soils have mainly $50 \%$ silty loam soils, $100 \%$ neutral $\mathrm{pH}$, and mostly $83 \%$ low to very low $\mathrm{C}$-org and $17 \%$ very high $\mathrm{C}$-org.

Stoichiometry C:N:P of SOM plays an important role in soil biogeochemistry (Knops and Tilman 2000; Clevel and Liptzin 2007). This is related to $C$ sequestration in the soil and amount of nutrients that can be stored and released into the soil. For instance, if the biomass has $\mathrm{C}: \mathrm{N}<25$, the mineralization will happen. Otherwise, if $\mathrm{C}: \mathrm{N}>35$, immobilization will occur. Also, if the $\mathrm{C}: \mathrm{P}<300$, the mineralization occurs, and at C:P >400, immobilization will occur (Macdonald and Baldock 2010). In particular, analysis of soils from Kupang and TTS regencies showed that mixed cropping has the highest $\mathrm{C}$-org than the dryland cropping system and forest lands. Soils from Kupang Regency have C-org in mixed cropping, agriculture, and forest, respectively, $1.8 \%, 1.1 \%$, and $1.1 \%$ (Moata et al. 2018). Meanwhile, TTS soils have C-org in mixed cropping, agriculture, and forest of $4.5 \%, 0.7 \%$, and $0.1 \%$, respectively.

This preliminary study showed that there was a strong correlation between soil organic carbon and C:N ( $r=0.90$; $\mathrm{p}=0.0004)$ and correlation with SOM:CEC (cation exchange capacity) $(r=0.64 ; \mathrm{P}=0.04)$. However, there was weak correlation with $\mathrm{C}: \mathrm{K}(r=0.51 ; \mathrm{p}=0.13)$. Finally, $\mathrm{C}: \mathrm{P}$ had a very weak correlation ( $r=0.30 ; \mathrm{p}=0.40$ ) (Figure 3 ).

These results showed that SOM that consists mainly of $\mathrm{C}$-org could be used as an indicator of soil nutrients and exchangeability. The increase of SOM (C-org) will increase $\mathrm{N}, \mathrm{K}$, and CEC in the soil. On the other hand, the C-org could not be an indicator of Ptot in the soil. Nevertheless, this evidence can not be absolutely accepted because the correlation of $\mathrm{C}: \mathrm{P}$ was very weak, almost no correlation. This weak correlation could be due to no correlation between C:Ptot and C:Porg (Moata et al. 2016). For dryland soils in the semi-arid region, this study resulted that these soils having $\mathrm{C}: \mathrm{N}=14$. Most likely, $\mathrm{P}$ soil is mainly weathered soils from the break down of Apatit mineral rather than SOM since these soils are dominated by low to very low SOM (C-org). Potassium (K) also has a weak correlation with $\mathrm{C}$ most probably is not from SOM, but other sources like Feldspar mineral.

To conclude, in general, West Timor soils have a dominant texture of clay and silty loam with neutral soil 
$\mathrm{pH}$. However, the SOM, C-org and soil nutrients (N, P, K) were categorized as low to very low levels. Stoichiometry of $\mathrm{C}: \mathrm{N}: \mathrm{P}$ in terrestrial semi-arid dryland soils has shown to have strong correlation of $\mathrm{C}: \mathrm{N}$ comparable to SOM:CEC. But the correlation was not clear for $\mathrm{C}: \mathrm{K}$ and $\mathrm{C}: \mathrm{P}$. It means SOM and C-org will direct $\mathrm{N}$ and the availability of nutrients in the soil from the increase of CEC. The stoichiometry of $\mathrm{C}: \mathrm{N}$ can help to predict mineralization and fertilizer input. But, still need further study on $\mathrm{P}_{\text {org }}$ and $\mathrm{K}$ soils to get better and clear understanding of the $\mathrm{C}: \mathrm{N}: \mathrm{P}: \mathrm{K}$ in dryland semi-arid soils.

\section{ACKNOWLEDGEMENTS}

We thank Kupang State Agricultural Polytechnic, Indonesia for research funding support from DIPA, 2018, in the research scheme PTUJ (Department of Applied Research). Thanks are also extended to all staff and field assistants for collecting soil samples and performing soil analysis.

\section{REFERENCES}

Aldrik JM. 1984. Phase II Feasibility and Design Study NTT Livestock Development Project Indonesia. Volume III The Land Resources of West Timor. ACIL Australia Pty. Ltd.

Anonymous. 1997. Pengelolaan Sumber Daya Lahan Kering di Indonesia Terjemahan dari Resource Management for Upland Areas in Southest Asia: An Information Kit. IIRR dan FAO. Jakarta. [Indonesian]

Baldock JA, Skjemstad JO. 1999. Soil organic carbon/soil organic matter. In: Peverill K, Sparrow L, Reuter DJ (eds) Soil Analysis: An Interpretation Manual. CSIRO Publishing, Melbourne.

Barrett JE, Virginia RA, Lyons WB, McKnight DM, Priscu JC, Doran PTF, Wall AG, Moorhead DL. 2007. Biogeochemical stoichiometry of Antarctic Dry Valley ecosystems. Geophys Res 112 (G01010): 1-2 DOI: 10.1029/2005JG000141.

Clapp CE, Hayes MHB, Simpson AJ, Kingery WL. 2005. Chemistry of soil organic matter. In: Al-Amoodi L, Dick W, Tabatabai A, Sparks D (eds) Chemical Processes in Soils. Soil Science Society of America Inc., USA. DOI: 10.2136/sssabookser8.c1.

Clevel C, Liptzin D. 2007. C:N:P stoichiometry in soil: is there a "Redfield ratio" for the microbial biomass? Biogeochemistry 85 (3): 235-252. DOI: 10.1007/s10533-007-9132-0.

Haynes RJ. 2005. Labile organic matter fractions as central components of the quality of agricultural soils: an overview. Adv Agron 85: 221-268. DOI: 10.1016/S0065-2113(04)85005-3.

Kirkby CA, Kirkegaard JA, Richardson AE, Wade LJ, Blanchard C, Batten G. 2011. Stable soil organic matter: A comparison of C:N:P:S ratios in Australian and other world soils. Geoderma 163 (3-4): $197-$ 208. DOI: 10.1016/j.geoderma.2011.04.010.

Kirkby CA, Richardson AE, Wade LJ, Batten GD, Blanchard C, Kirkegaard JA. 2013. Carbon-nutrient stoichiometry to increase soil carbon sequestration. Soil Biol Biochem 60, 77-86. DOI: 10.1016/j.soilbio.2013.01.011.

Knops JMH, Tilman D. 2000. Dynamic of soil nitrogen and carbon accumulation for 61 years after agricultural abandonment. Ecology 81 (1): $\quad 88-89 . \quad$ DOI: $10.1890 / 0012$ 9658(2000)081[0088:DOSNAC]2.0.CO;2.

Macdonald LM, Baldock JA. 2010. Manipulating soil carbon and nutrients: advancing understanding of soil cycling using approaches based on ecological stoichiometry. National Research Flagships, Sustainable Agriculture, CSIRO Land and Water, S. Aust./GRDC, Barton, ACT.

Moata, MRS, Smernik RJ, Doolette AL, McNeill AM, Macdonald LM. 2015. Improving sensitivity of solution ${ }^{31} \mathrm{P}$ NMR analysis in Australian Xeralfs. Commun Soil Sci Plant Anal 46 (8): 1034-1043. DOI: $10.1080 / 00103624.2015 .1019081$.

Moata MRS, Doolette AL, Smernik RJ, McNeill AM, Macdonald LM. 2016. Organic phosphorus speciation in Australian Red Chromosols: Stoichiometric control. Soil Res 54 (1): 11-19. DOI: 10.1071/SR15085.

Moata MRS, Takalapeta A, Puay Y, Kollo O, Tlonaen C. 2018. Monitoring Kualitas Tanah di Lahan Kering sebagai Upaya Menunjang Ketahanan Pangan di Wilayah Semi Arid. Prosiding Seminar Nasional Pertanian Ke V. Pengelolaan Pertanian Lahan Kering Berkelanjutan untuk Menunjang Kedaulatan Pangan, Kupang 26 Oktober 2018. [Indonesian]

Nur MSM. 2018. Peta Pengembangan Lahan Kering di Provinsi NTT. Makalah. Forum Ekonomi dan Bisnis tetang Pengembangan Lahan Kering di Prov. NTT. Bappeda NTT. 19 September 2018. [Indonesian]

Ramesh T, Manjaiah KM, Mohopatra KP, Rajasekar K, Ngachan SV. 2015. Assessment of soil organic carbon stocks and fractions under different agroforestry systems in subtropical hill agroecosystems of northeast India. Agrofor Syst 89 (4): 677-690. DOI 10.1007/s10457015-9804-z.

Sinsabaugh RL, Lauber C, Weintraub MN, Ahmed B, Allison SD, Crenshaw C, Contosta AR, Cusack D, Frey S, Gallo ME, Gartner TB, Hobbie SE, Holland K, Keeler BL, Powers JS, Stursova M, TakacsVesbach C, Waldrop MP, Wallenstein MD, Zak DR, Zeglin LH. 2008. Stoichiometry of soil enzyme activity at global scale. Ecol Lett 11 (11): 1252-1264. DOI: 10.1111/j.1461-0248.2008.01245.x.

Six J, Guggenberger G, Pautian K, Haumaier L, Elliot EL, Zech W. 2001. Sources and composition of soil organic matter fractions between and within soil aggregates. Eur J Soil Sci 52 (4): 607-618. DOI: 10.1046/j.1365-2389.2001.00406.x.

Tian H, Chen G, Zhang C, Melillo JM, Hall CAS. 2010. Pattern and variation of $\mathrm{C}: \mathrm{N}: \mathrm{P}$ ratios in China's soils: a synthesis of observational data. Biogeochemistry 98 (1): 139-151. DOI: 10.1007/s10533-0099382-0

Yang Y, Luo Y. 2011. Carbon: Nitrogen stoichiometry in forest ecosystems during stand development. Glob Ecol Biogeogr 20 (4): 354-361. DOI: $10.1111 / \mathrm{j} .1466-8238.2010 .00602 . x$. 